\title{
Association of the DRD2 TaqIA, 5-HT1B A-161T, and CNR1 1359 G/A Polymorphisms with Alcohol Dependence
}

\author{
Melike Ceyhan Balci Sengul', Cem Sengul ${ }^{2}$, Mehmet Emin Erdal ${ }^{3}$, Ozlem Izci Ay ${ }^{4}$, Muharrem Efe ${ }^{5}$, \\ Mustafa Ertan $\mathrm{Ay}^{4}$, Hasan Herken ${ }^{6}$
}

ÖZET:

DRD2 TaqIA, 5-HT1B A-161T VE CNR1 1359 G/A polimorfizmlerinin alkol bağımlılığı ile ilişkisi

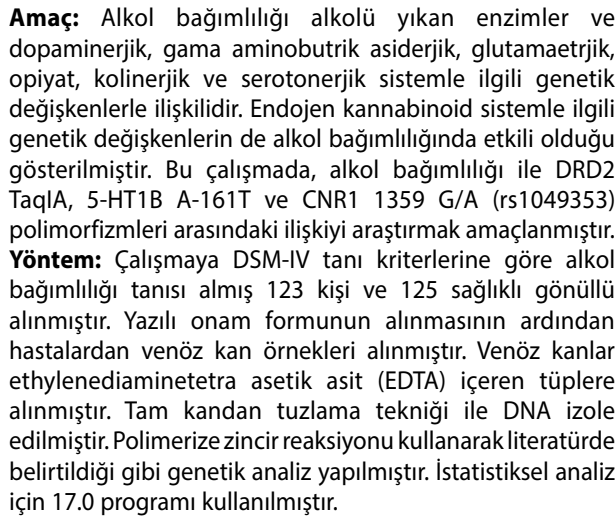
Bulgular: DRD TaqIA polimorfizmi hem çalışma hem de kontrol grubunda analiz edilmiştir. Çalışma grubunda, A1/ A1 genotipi 5 kişide (4.0\%), A1/A2 genotipi 51 (41.5\%) kişide ve A2/A2 genotipi 67 (54.5\%) kişide saptanmıştır. Kontrol grubunda ise, $\mathrm{A} 1 / \mathrm{A} 1$ genotipi 6 (4.8\%) kişide, $\mathrm{A} 1 / \mathrm{A} 2$ genotipi 40 (32.0\%) kişide A2/A2 genotipi 79 (62.2\%) kişide saptanmıștır. 5-HT1B reseptör A-161T gen polimorfizmi için ise, A/A genotipi 61 (49.6\%) kişide, $A / T$ genotipi 53 (43.1\%) ve $\mathrm{T} / \mathrm{T}$ genotipi (7.3\%) kişide tespit edilmiştir. Kontrol grubunda ise, A/A genotipi 84 (67.2\%), A/T genotipi 39 (31.2\%) ve T/T genotipi 2 (1.6\%) kişide tespit edilmiştir. CNR1 1359 polimorfizmi için ise G/G genotipi hem çalışma hem de kontrol grubunda en sık saptanan polimorfizmdir. Çalışma grubunda $75(61.0 \%)$ kişide, kontrol grubunda ise $84(67.2 \%)$ kişide bu polimorfizm görülmüștür. G/A genotipi ise çalışma grubunda $39(31.7 \%)$ kişide, kontrol grubunda ise 38 (30.4\%) kișide görülmüștür. A/A genotipi hem çalışma hem de kontrol grubunda en nadir görülen genotiptir ve çalışma grubunda sadece 9 (7.3\%) kişide, kontrol grubunda ise 3 (2.4\%) kişide gözlenmiş̧ir. Çalışılan 3 polimerimden sadece 5-HT1B A-161T polimorfizmi alkol bağımlıı̆̆ı ile ilişkili bulunmuştur.

Sonuç: 5-HT1B reseptör A-161T polimorfizmi alkol bağımlılığı için umut veren bir belirteç olabilir, ancak bu bulguları netleştirmek için ileri çalışmalara intiyaç duyulmaktadır.

Anahtar sözcükler: alkol bağımlılı̆ı̆, DRD2 TaqlA, 5-HT1B A-161T, CNR1 $1359 \mathrm{G} /$ A polimorfizmi

Klinik Psikofarmakoloji Bulteni 2014;24(2):115-21
ABSTRACT:

Association of the DRD2 TaqIA, 5-HT1B A-161T, and CNR1 $1359 \mathrm{G} / \mathrm{A}$ polymorphisms with alcohol dependence

Objective: Alcohol dependence is associated with genetic variants of alcohol-metabolizing enzymes and genes related to dopaminergic, gamma-aminobutyric acidergic, glutamatergic, opioid, cholinergic, and serotonergic systems. Genetic variations in the endogenous cannabinoid system are also involved in alcohol dependence. The present study aimed to evaluate the association between three polymorphisms, DRD2 TaqIA, 5-HT1B A-161T and CNR1 $1359 \mathrm{G} / \mathrm{A}$ (rs1049353), and alcohol dependence.

Methods: One hundred twenty three patients, who were diagnosed as having alcohol dependence according to the DSM-IV criteria and 125 healthy volunteers, were included in the study. With written informed consent, a blood sample was drawn from each individual. Venous blood samples were collected in ethylenediaminetetra acetic acid (EDTA) containing tubes. DNA was extracted from whole blood by the salting out procedure. Genetic analyses were performed as described in the literature by using a Polymerase Chain Reaction method. SPSS 17.0 software was used for statistical analysis.

Results: The DRD2 TaqIA polymorphism was analyzed in the study and control groups. In the study group, the $A 1 /$ A1 genotype was observed in $5(4.0 \%)$ patients, the $\mathrm{A} 1 /$ A2 genotype was observed in 51 (41.5\%) patients and the A2/A2 genotype was observed in 67 (54.5\%) patients. In the control group, the A1/A1 genotype was observed in 6 (4.8\%) subjects, the $\mathrm{A} 1 / \mathrm{A} 2$ genotype was observed in 40 (32.0\%) subjects and the $A 2 / A 2$ genotype was observed in $79(62.2 \%)$ subjects. For the 5 -HT1B receptor A-161T gene polymorphism, the $A / A$ genotype was detected in $61(49.6 \%)$ patients, the $A / T$ genotype was detected in 53 (43.1\%) and the T/T genotype was detected in 9 (7.3\%) patients. In the control group, the A/A genotype was detected in $84(67.2 \%)$ subjects, the $A / T$ genotype was detected in 39 (31.2\%) subjects, and the T/T genotype was detected only in $2(1.6 \%)$ subjects. The $\mathrm{G} / \mathrm{G}$ genotype was the most common genotype in both study and control groups for CNR1 1359 gene polymorphism. It was detected in $75(61.0 \%)$ study patients and in $84(67.2 \%)$ control subjects. The G/A genotype was observed in 39 (31.7\%) patients of the study group and $38(30.4 \%)$ subjects of the control group. The A/A genotype was the most rare genotype in both groups; it was detected only in 9 (7.3\%) study patients and $3(2.4 \%)$ control subjects. Of the three polymorphisms investigated, 5-HT1B A-161T was the only one found to be associated with alcohol dependence.

Conclusions: The $5-\mathrm{HT} 1 \mathrm{~B}$ receptor A-161T polymorphism might be a promising marker for alcohol dependence; however, future studies are needed to clarify these findings.

Keywords: alcohol dependence, DRD2 TaqIA, 5-HT1B A-161T, CNR1 $1359 \mathrm{G} / \mathrm{A}$, polymorphism

Bulletin of Clinical Psychopharmacology 2014;24(2):115-21
'Assist. Prof., ${ }^{2}$ Assoc. Prof., ${ }^{6}$ Prof., Pamukkale University School of Medicine, Department of Psychiatry, Denizli - Turkey

${ }^{3}$ Prof., ${ }^{4}$ Asisst. Prof., Mersin University School of Medicine, Department of Medical Biology and Genetics, Mersin - Turkey

${ }^{5}$ M.D., Iskilip Atif Hoca State Hospital Psychiatry Clinic, Corum - Turkey

Address reprint requests to: Cem Sengul, Pamukkale Üniversitesi Psikiyatri Anabilim Dalı, Denizli - Türkiye

E-mail address:

acemsen@gmail.com

Date of submission: November 07, 2013

Date of acceptance: December 29, 2013

Declaration of interest: M.C.B.S., C.S., M.E.E., O.I.A., M.E., M.E.A., H.H.: The authors reported no conflict of interest related to this article. 


\section{INTRODUCTION}

Alcohol dependence, a chronic relapsing disorder, is characterized by repetitive alcohol drinking patterns causing a loss of control over alcohol consumption ${ }^{1}$. Susceptibility to the development of alcohol dependence is associated with $50 \%-60 \%$ heritability among both males and females ${ }^{2}$.Thehighheritabilityofalcoholdependence indicates that genetic factors are important in the disease process. Until recently, the only genes unambiguously associated with variation in the risk of developing alcoholism were those that encode alcohol-metabolizing enzymes and neurotransmitters, such as dopamine, gammaaminobutyric acid (GABA) and serotonin ${ }^{3}$. More recently, studies on epigenetic factors and possible associations of genes involved in the cannabinoid and opiate systems are on the rise.

Polymorphisms in genes encoding the neurotransmitters and enzymes intrinsically involved in addiction have been investigated in candidate gene studies. Associations between alcohol dependence and genetic variants of alcoholmetabolizing enzymes and genes related to dopaminergic, GABAergic, glutamatergic, opioid, cholinergic, and serotonergic systems have been intensively investigated ${ }^{4}$. Dopamine is one of the most frequently studied neurotransmitters in addiction genetics, and the dopamine receptor D2 (DRD2) TaqI-A1 polymorphism was the first gene polymorphism associated with alcohol dependence $^{5,6}$. In their meta-analysis, Smith and colleagues reported that individuals with the A1A1 and A1A2 genotypes were 1.38 times more at risk for alcoholism than those with the A2A2 genotype ${ }^{7}$. Several major lines of evidence have supported the role of dysfunction of the human serotonin receptor (5-HT1B) in the pathophysiology of alcohol dependence $^{8}$. It has been reported that 5-HT1B knockout mice show greater aggression, impulsivity, and alcohol and cocaine consumption ${ }^{9,10}$. Many genetic variants of the 5-HT1B gene have been determined by polymerase chain reaction, and the A-161T polymorphism in the promoter region of the 5-HT1B receptor gene has been found to be associated with alcohol dependence ${ }^{11}$. Researchers have also suggested that the endocannabinoid system may play a role in many of the physiological and behavioral effects of chronic ethanol exposure, including tolerance and dependence ${ }^{12}$. Various genetic variations in the endocannabinoid system have also been associated with different kinds of substance abuse ${ }^{13}$. Studies regarding the association of the cannabinoid receptor 1 (CNR1) 1359 G/A (rs1049353) polymorphism with alcoholism have reported an excess frequency of the A allele in alcoholics versus healthy controls ${ }^{14}$. These results, however, are controversial, since this observation was not replicated in other studies ${ }^{15}$.

The primary goal of the present study was to investigate the underlying genetic mechanisms of neurotransmitters that were related to the neurobiology of alcohol addiction (dopaminergic, serotonergic and endocannabinoid). Association between DRD2 TaqIA, 5-HT1B A-161T and CNR1 1359 G/A (rs1049353) polymorphisms and alcohol dependence was investigated in patients with alcohol dependence and healthy control subjects.

\section{MATERIALS AND METHODS}

\section{Subjects}

The present study was conducted in the Alcohol and Substance Abuse Center of Denizli State Hospital. Thestudywas approved bytheLocalEthicsCommittee, and all participants provided written informed consent. Randomly selected patients between 18 and 65 years of age with a diagnosis of alcohol dependence according to DSM-IV criteria were included in the present study. The Structured Clinical Interview for the DSM-IV (SCID-I) was used to evaluate the patients, and patients with any axis I disorder other than smoking dependence were excluded from the study. Patients were also excluded if they had clinically significant organic disorders, mental retardation or a history of substance abuse (except alcohol and tobacco) in the previous 12 months. The control group consisted of 125 volunteers, whose demographic characteristics were suitable for the study, who had no severe chronic physical diseases and no history of 
mental disorders, who were not related to the patients in the study group, and who were willing to participate in the study. Our study and control group all were of Turkish origin.

Patients were assessed for inclusion criteria on their first day of hospitalization. A semi-structured questionnaire, which was developed by the researchers, consisting of items covering sociodemographic data and detailed history of alcohol use was administered to all patients.

\section{Molecular Analysis}

With written informed consent, a venous blood sample was drawn from each individual into tubes containing ethylenediaminetetraacetic acid (EDTA). DNA was extracted from whole blood by a previously described salting-out procedure ${ }^{16}$.

A Polymerase Chain Reaction-Restriction Fragment Length Polymorphism (PCR-RFLP) assay was used to determine the Taq1A (rs17115461) polymorphism within the DRD2 gene. The oligonucleotide primers, used to amplify the region containing this polymorphism, have been described previously ${ }^{17}$. The genotyping of the CNR1 1359 G/A (rs1049353) and 5-HT1B A-161T (rs130058) polymorphisms was performed using a predesigned TaqMan Single Nucleotide Polymorphism (SNP) Genotyping Assay (Applied Biosystems, Foster City, CA, USA). The Assays-on-Demand SNP genotyping kit (Applied Biosystems) was used for the real-time polymerase chain reaction. All SNP amplification assays were performed in accordance with the manufacturer's instructions. All procedures were performed in a blinded manner to the status of the patients and other characteristics of the participants. Two independent investigators scored the gel images and entered the data.

\section{Statistical Analysis}

The Predictive Analysis Software (PASW) Statistics 17.0 (SPSS Inc., Chicago, IL, USA) was used for statistical analysis. Descriptive analysis was used for sociodemographic data. The chi-square test was used for categorical and the t test was used for continuous variables. A $p$ value of $<0.05$ was considered statistically significant.

\section{RESULTS}

The study group consisted of 123 patients with alcohol dependence [111 (90.2\%) males; 12 (9.8\%) females] and the control group comprised 125 healthy volunteers [111 (88.7\%) males; 14 (11.2\%) females]. The mean age of the study group was $35.19 \pm 10.18$ years, and the mean age of the control group was $34.53 \pm 14.22$ years. There were no statistically significant differences between the study and control groups in terms of age and gender ( $p>0.05)$. The social demographic factors of the study and control groups are shown in Table 1.

The DRD2 Taq1A polymorphism was analyzed in the study and control groups. In the study group, the Al/Al genotype was observed in $5(4.0 \%)$ patients, the A1/A2 genotype was observed in 51 (41.5\%) patients, and the A2/A2 genotype was observed in $67(54.5 \%)$ patients. In the control group, the Al/Al genotype was observed in 6 (4.8\%) subjects, the A1/A2 genotype was observed in 40 (32.0\%) subjects, and the A2/A2 genotype was observed in $79(62.2 \%)$ subjects. The Al allele was found in 56 (32.2\%) study subjects and 46 (26.3\%) controls. The A2 allele was found 118 (67.8\%) study subjects and 119 (73.7\%) of the control group. There was no statistically significant difference between the study and control groups in terms of the

Table 1: Sociodemographic characteristic of the participants

\begin{tabular}{lccc} 
& $\begin{array}{c}\text { Alcohol Group } \\
(\mathbf{n = 1 2 3 )}\end{array}$ & $\begin{array}{c}\text { Control Group } \\
(\mathbf{n = 1 2 5})\end{array}$ & P value \\
\hline Age & $35.19 \pm 10.18$ & $34.53 \pm 14.22$ & 0.67 \\
Education (years) & $7.9 \pm 3.2$ & $8.4 \pm 3.2$ & 0.49 \\
Employment (years) & $7.2 \pm 3.4$ & $8.1 \pm 3.9$ & 0.21 \\
Smoking (n) & 86 & 76 & 0.43 \\
Cigarette per day & $18.2 \pm 7.8$ & $15.6 \pm 6.1$ & 0.37
\end{tabular}


Table 2: Distribution of the genotypes and alleles of the DRD2 Taq1A, 5-HT1B A-161T, and CNR1 1359 G/A polymorphisms in the study and control groups

\begin{tabular}{|c|c|c|c|c|c|c|c|}
\hline \multirow[b]{2}{*}{$\begin{array}{l}\text { DRD2 Taq1A } \\
\text { polymorphism }\end{array}$} & \multicolumn{3}{|c|}{ Study Group ( $n=123)$} & \multicolumn{3}{|c|}{ Control Group $(n=125)$} & \multirow{2}{*}{$\frac{\mathbf{p}}{0.30}$} \\
\hline & $\begin{array}{l}\mathrm{A} 1 / \mathrm{A} 1 \\
5(4.0)\end{array}$ & $\begin{array}{l}\text { A1/A2 } \\
51(41.5)\end{array}$ & $\begin{array}{l}\text { A2/A2 } \\
67(54.5)\end{array}$ & $\begin{array}{l}\mathrm{A} 1 / \mathrm{A} 1 \\
6(4.8)\end{array}$ & $\begin{array}{l}\mathrm{A} 1 / \mathrm{A} 2 \\
40(32.0)\end{array}$ & $\begin{array}{l}\text { A2/A2 } \\
79(62.2)\end{array}$ & \\
\hline DRD2 Taq1A allele & $\begin{array}{l}\text { A1 allele } \\
56(32.2)\end{array}$ & & $\begin{array}{l}\text { A2 allele } \\
118(67.8)\end{array}$ & $\begin{array}{l}\text { A1 allele } \\
46(26.3)\end{array}$ & & $\begin{array}{l}\text { A2 allele } \\
119 \text { (73.7) }\end{array}$ & 0.27 \\
\hline $\begin{array}{l}\text { 5-HT1B A-161T } \\
\text { polymorphism }\end{array}$ & $\begin{array}{l}\text { A/A } \\
61(49.6)\end{array}$ & $\begin{array}{l}\mathrm{A} / \mathrm{T} \\
53(43.1)\end{array}$ & $\begin{array}{l}\mathrm{T} / \mathrm{T} \\
9(7.3)\end{array}$ & $\begin{array}{l}\text { A/A } \\
84(67.2)\end{array}$ & $\begin{array}{l}\mathrm{A} / \mathrm{T} \\
39(31.2)\end{array}$ & $\begin{array}{l}\mathrm{T} / \mathrm{T} \\
2(1.6)\end{array}$ & 0.001 \\
\hline $\begin{array}{l}\text { 5-HT1B A-161T } \\
\text { allele }\end{array}$ & $\begin{array}{l}\text { A allele } \\
114(64.8)\end{array}$ & & $\begin{array}{l}\text { T allele } \\
62(35.2)\end{array}$ & $\begin{array}{l}\text { A allele } \\
123(74.5)\end{array}$ & & $\begin{array}{l}\text { T allele } \\
41(25.5)\end{array}$ & 0.002 \\
\hline $\begin{array}{l}\text { CNR1 } 1359 \mathrm{G} / \mathrm{A} \\
\text { polymorphism }\end{array}$ & $\begin{array}{l}\mathrm{G} / \mathrm{G} \\
75(61.0)\end{array}$ & $\begin{array}{l}\mathrm{G} / \mathrm{A} \\
39(31.7)\end{array}$ & $\begin{array}{l}A / A \\
9(7.3)\end{array}$ & $\begin{array}{l}\mathrm{G} / \mathrm{G} \\
84(67.2)\end{array}$ & $\begin{array}{l}\mathrm{G} / \mathrm{A} \\
38(30.4)\end{array}$ & $\begin{array}{l}\mathrm{A} / \mathrm{A} \\
3(2.4)\end{array}$ & 0.17 \\
\hline CNR1 1359 allele & $\begin{array}{l}\text { G allele } \\
114(70.4)\end{array}$ & & $\begin{array}{l}\text { A allele } \\
48(29.6)\end{array}$ & & $\begin{array}{l}\text { G allele } \\
122(74.8)\end{array}$ & $\begin{array}{l}\text { A allele } \\
41(25.2)\end{array}$ & 0.13 \\
\hline
\end{tabular}

distribution of genotypes and alleles of the DRD2 Taq1A polymorphism ( $>0.05)$.

The A-161T polymorphism of the 5-HT1B receptor gene was also studied in both groups. In the study group, the A/A genotype was detected in 61 (49.6\%) patients, the A/T genotype was detected in $53(43.1 \%)$ patients, and the T/T genotype was detected in 9 (7.3\%) patients. In the control group, the A/A genotype was detected in $84(67.2 \%)$ subjects, the A/T genotype was detected in 39 (31.2\%) subjects, and the T/T genotype was detected only in $2(1.6 \%)$ subjects. The A allele was found in $114(64.8 \%)$ of the study and $123(74.5 \%)$ of the control group. The $\mathrm{T}$ allele was found in 62 (35.2.8\%) of study and $41(25.5 \%)$ of the control group. There was a significant difference between the study and control groups in terms of the distribution of genotypes and alleles of the A-161T polymorphism of the 5-HT1B receptor gene $(\mathrm{p}<0.05)$.

The CNR1 1359 G/A polymorphism was not found to be associated with alcohol dependence. The G/G genotype was the most common genotype in both study and control groups; it was detected in $75(61.0 \%)$ study patients and in $84(67.2 \%)$ control subjects. The G/A genotype was observed in 39 (31.7\%) patients of the study group and $38(30.4 \%)$ subjects of the control group. The A/A genotype was the most rare genotype in both groups; it was detected only in $9(7.3 \%)$ study patients and $3(2.4 \%)$ control subjects. The $\mathrm{G}$ allele was found in 114 (70.4\%) of the study and $122(74.8 \%)$ of the control group. The A allele was found in 48 (29.68\%) of study and $41(25.2 \%)$ of control group. No statistically significant difference was found between the study and control groups in terms of the distribution of genotypes and alleles of the CNR1 1359 G/A polymorphism $(p>0.05)$. The distribution of the genotypes of the DRD2 Taq1A polymorphism, 5-HT1B A-161T polymorphism, and CNR1 1359 G/A polymorphism in the study and control groups are presented in Table 2.

\section{DISCUSSION}

Genetics is one of the most rapid developing fields of medicine. New technologies such as the genome-wide association and copy number variants studies are promising to provide novel insights that might lead to new treatments for alcohol dependence ${ }^{18}$. However, studies investigating SNPs still constitute the majority of studies in the literature. Few genetic studies on alcohol dependence have been carried out in the Turkish population. Cinnioglu and collagues reported that Turkish subjects were genetically similar to those from European, Caucasian, and Middle Eastern populations ${ }^{19}$. Kayaalti and Soylemezoglu found that genotype distributions of ADH1B, ALDH2, 
CYP2E1*6, and CYP2E1*7B in the Turkish population were similar to those in Caucasian and some European populations, whereas they differed significantly from those in East Asian populations ${ }^{20}$. Kortunay et al. also reported that the frequencies of variant $\mathrm{ADH} 3$ alleles and genotypes were similar to those in other Caucasian populations ${ }^{21}$.

In the present study, we investigated the association of DRD2 TaqIA, 5-HT1B A-161T, and CNR1 1359 G/A (rs1049353) polymorphisms with alcohol dependence. The DRD2 TaqIA polymorphism is one of the most widely studied gene polymorphisms in alcohol dependence. We failed to detect any association between alcoholdependent Turkish patients and the DRD2 Taq1A polymorphism. Association of DRD2 TaqIA polymorphism with alcoholism was first reported by Blum et al. in $1990^{5}$. Since then, numerous studies have been published, several of which have shown an increase in the DRD2 A1 allele frequency associated with alcohol dependence ${ }^{22}$. Recently, Lee and colleagues found an association between DRD2 TaqIA polymorphism and alcohol dependence in the Korean population ${ }^{23}$. There are several studies, however, in which no evidence has been demonstrated for association of the DRD2 A1 allele with alcoholism ${ }^{21}$. In a meta-analysis on this topic, authors have reported that association of the A1 allele with alcoholism may be relatively small because a complex disorder like alcohol dependence has a multigene causality ${ }^{7,22}$. Our results were in agreement with the negative results. Causes of these findings might be sample size of the present study rather than a special genetic feature of the Turkish population.

Research performed during the past 30 years has indicated that serotonin neurotransmission is associated with alcohol dependence ${ }^{24}$. The serotonergic system has been shown to be important in mediating alcohol reward, preference, dependence, and craving ${ }^{25}$. Studies concerning the association of alcohol dependence with serotonin polymorphisms generally have focused on the serotonin transporter gene. The short, low-activity allele of a polymorphism in the serotonin transporter gene (SLC6A4) has been linked to alcohol dependence ${ }^{26}$. In a recent meta-analysis, McHugh et al. also concluded that the short allele of the 5-HTTLPR SLC6A4 polymorphism was associated with alcohol dependence ${ }^{27}$. Genetic polymorphisms in serotonin receptors have been another important topic in alcohol dependence ${ }^{28}$. It has been suggested that alcohol dependence is associated with elevations in the number of serotonin $1 \mathrm{~B}$ receptors in animal models, and that alcohol dependence is associated with elevated levels of ventral striatal 5 -HT1B receptors in humans, like in rodent models ${ }^{29}$. Several polymorphisms in the 5-HT1B receptor gene have been detected, and of these, T371G, A-161T, and G861C have been found to be associated with different psychiatric disorders ${ }^{30}$. The A-161T polymorphism is located in the promoter region of the $5 \mathrm{HT} 1 \mathrm{~B}$ receptor gene, and this polymorphism might alter transcriptional expression of the receptor $^{31}$. Sun et al. reported the variant A-161T to be associated with alcohol dependence at both the allelic and genotypic level in a Taiwanese Han population $^{31}$. Cao et al. also found an association between this polymorphism and alcohol dependence in 135 male Han Chinese patients ${ }^{32}$. They suggested that the A-161T polymorphism might be a valuable genetic marker for detecting alcohol dependence. In agreement with this finding, we also found an association between alcohol dependence and the A-161T polymorphism in the present study. In contrast to these results, two papers from the literature have reported no association between alcohol dependence and the A-161T polymorphism ${ }^{33,34}$.

We investigated the possibility of an association between the rs 1049353 polymorphism of CNR1 and alcohol dependence, but failed to detect any difference between the alcohol-dependent and control groups in the present study. There is increasing evidence from pharmacologic and neurochemical studies that the endogenous cannabinoid system is involved in addiction to substance abuse. Of the two known cannabinoid receptors, the receptor which is mainly responsible for neurophysiological and behavioral responses related to addictive behavior is $\mathrm{CNR} 1^{35}$. The 
association of three polymorphisms in CNR1 (rs1049353, rs806379, and AAT repeat) with substance dependence has been reported in the literature. Despite 2 reports in which, an association was found in alcoholics, a recent meta-analysis consisting of five studies did not show a significant association, in agreement with the results of the present study ${ }^{36,37}$.

The current study has limitations such as small sample size and lack of examination of personality traits. Moreover, the consideration of how single nucleotide polymorphisms effect alcohol addiction is difficult because alcohol addiction is a complex polygenetic process.

\section{CONCLUSION}

Of the three genetic polymorphisms investigated in the present study, only the A-161T polymorphism of the $5-\mathrm{HT} 1 \mathrm{~B}$ receptor gene resulted in detection of a significant association. Although there are a limited number of studies and contradictory results, the 5 -HT1B receptor A-161T polymorphism may be a promising marker for alcohol dependence.

\section{References:}

1. Koob GF. Alcoholism: allostasis and beyond. Alcohol Clin Exp Res 2003;27(2):232-43. [CrossRef]

2. Prescott CA, Kendler KS. Genetic and environmental contributions to alcohol abuse and dependence in a population-based sample of male twins. Am J Psychiatry 1999;156(1):34-40.

3. Edenberg HJ, Dick DM, Xuei X, Tian H, Almasy L, Bauer LO, et al. Variations in GABRA2, encoding the alpha 2 subunit of the GABA(A) receptor, are associated with alcohol dependence and with brain oscillations. Am J Hum Genet 2004;74(4):705-14. [CrossRef]

4. Sengul C, Sengul CB, Okay T, Dilbaz N. Memantine as an add-on therapy in alcohol withdrawal syndrome. Klinik Psikofarmakoloji Bülteni-Bulletin of Clinical Psychopharmacology 2009;19:359-364. (Turkish)

5. Blum K, Noble EP, Sheridan PJ, Montgomery A, Ritchie $\mathrm{T}$, Jagadeeswaran $\mathrm{P}$, et al. Allelic association of human dopamine D2 receptor gene in alcoholism. JAMA 1990;263(15):2055-60. [CrossRef]

6. Berggren U, Fahlke C, Aronsson E, Karanti A, Eriksson M, Blennow $\mathrm{K}$, et al. The taqI DRD2 A1 allele is associated with alcohol-dependence although its effect size is small. Alcohol Alcohol 2006;41(5):479-85. [CrossRef]

7. Smith L, Watson M, Gates S, Ball D, Foxcroft D. Meta-analysis of the association of the Taq1A polymorphism with the risk of alcohol dependency: A HuGE gene-disease association review. Am J Epidemiol 2008;167(2):125-38. [CrossRef]

8. van Munster BC, de Rooij SE, Yazdanpanah M, Tienari PJ, Pitkälä KH, Osse RJ, et al. The association of the dopamine transporter gene and the dopamine receptor 2 gene with delirium, a meta-analysis. Am J Med Genet B Neuropsychiatr Genet 2010;153B(2):648-55.

9. Crabbe JC, Belknap JK, Buck KJ. Genetic animal models of alcohol and drug abuse. Science 1994;264(5166):1715-23. [CrossRef]
10. Crabbe JC, Phillips TJ, Feller DJ, Hen R, Wenger CD, Lessov CN. Elevated alcohol consumption in null mutant mice lacking 5-HT1B serotonin receptors. Nat Genet 1996;14(1):98-101. [CrossRef]

11. Drago A, Alboni S, Brunello N, De Ronchi D, Serretti A. HTR1B as a risk profile maker in psychiatric disorders: a review through motivation and memory. Eur J Clin Pharmacol 2010;66(1):5-27. [CrossRef]

12. Beardsley PM, Thomas BF, McMahon LR. Cannabinoid CB1 receptor antagonists as potential pharmacotherapies for drug abuse disorders. Int Rev Psychiatry 2009;21(2):134-42. [CrossRef]

13. Racz I, Bilkei-Gorzo A, Toth ZE, Michel K, Palkovits M, Zimmer A. A critical role for the cannabinoid CB1 receptors in alcohol dependence and stress-stimulated ethanol drinking. J Neurosci 2003;23(6):2453-8.

14. Schmidt LG, Samochowiec J, Finckh U, Fiszer-Piosik E, Horodnicki J, Wendel B, et al. Association of a CB1 cannabinoid receptor gene (CNR1) polymorphism with severe alcohol dependence. Drug Alcohol Depend 2002;65(3):221-4. [CrossRef]

15. Zuo L, Kranzler HR, Luo X, Covault J, Gelernter J. CNR1 variation modulates risk for drug and alcohol dependence. Biol. Psychiatry 2007;62(6):616-26. [CrossRef]

16. Miller SA, Dykes DD, Polesky HF. A simple salting out procedure for extracting DNA from human nucleated cells. Nucleic Acids Res 1988;16(3):1215. [CrossRef]

17. Ponce G, Hoenicka J, Rodríguez-Jiménez R, Gozalo A, Jimenéz M, Monasor R, et al. IDRD2 TaqIA polymorphism is associated with urinary homovanillic acid levels in a sample of Spanish male alcoholic patients. Neurotox Res 2004;6(5):373-7. [CrossRef]

18. Rudan I. New technologies provide insights into genetic basis of psychiatric disorders and explain their co-morbidity. Psychiatr Danub 2010;22(2):190-2. 
19. Cinnioğlu C, King R, Kivisild T, Kalfoğlu E, Atasoy S, Cavalleri GL, et al. Excavating Y-chromosome haplotype strata in Anatolia. Hum Genet 2004;114(2):127-48. [CrossRef]

20. Kayaaltı Z, Söylemezoğlu T. Distribution of ADH1B, ALDH2, CYP2E1 ${ }^{*} 6$, and CYP2E1 $* 7 B$ genotypes in Turkish population. Alcohol 2010;44(5):415-23. [CrossRef]

21. Kortunay S, Yasar U, Isik T, Bozkurt A, Babaoglu MO. Variant alleles and genotypes of alcohol dehydrogenase 3 in a Turkish population. Methods Find Expr Clin Pharmacol 2006;28(4):229-31. [CrossRef]

22. Noble EP. D2 dopamine receptor gene in psychiatric and neurologic disorders and its phenotypes. Am J Med Genet B Neuropsychiatr Genet 2003;116B(1):103-25. [CrossRef]

23. Lee SH, Lee BH, Lee JS, Chai YG, Choi MR, Han DM, et al. The association of DRD2 -141C and ANKK1 TaqIA polymorphisms with alcohol dependence in Korean population classified by the Lesch typology. Alcohol Alcohol 2013;48(4):426-32. [CrossRef]

24. Pettinati HM, Kranzler HR, Madaras J. The status of serotonin-selective pharmacotherapy in the treatment of alcohol dependence. Recent Dev Alcohol 2003;16:247-6. [CrossRef]

25. Sari Y, Johnson VR, Weedman JM. Role of the serotonergic system in alcohol dependence: from animal models to clinics. Prog Mol Biol Transl Sci 2011;98:401-43. [CrossRef]

26. van der Zwaluw CS, Engels RC, Vermulst AA, Rose RJ, Verkes RJ, Buitelaar J, et al. A serotonin transporter polymorphism (5-HTTLPR) predicts the development of adolescent alcohol use. Drug Alcohol Depend 2010;112(1-2):134-9. [CrossRef]

27. McHugh RK, Hofmann SG, Asnaani A, Sawyer A, Otto MW. The serotonin transporter gene and risk for alcohol dependence: a meta-analytic review. Drug Alcohol Depend 2010;108(1-2):1-6. [CrossRef]

28. Polina ER, Contini V, Hutz MH, Bau CH. The serotonin 2A receptor gene in alcohol dependence and tobacco smoking. Drug Alcohol Depend 2009;101(1-2):128-31. [CrossRef]
29. Hu J, Henry S, Gallezot JD, Ropchan J, Neumaier JF, Potenza MN, et al. Serotonin 1B receptor imaging in alcohol dependence. Biol Psychiatry 2010;67(9):800-3. [CrossRef]

30. Sanders AR, Duan J, Gejman PV. DNA variation and psychopharmacology of the human serotonin receptor 1B (HTR1B) gene. Pharmacogenomics 2002;3(6):745-62. [CrossRef]

31. Sun HF, Chang YT, Fann CS, Chang CJ, Chen YH, Hsu YP, et al. Association study of novel human serotonin 5-HT(1B) polymorphisms with alcohol dependence in Taiwanese Han Biol Psychiatry 2002;51(11):896-901.

32. Cao JX, Hu J, Ye XM, Xia Y, Haile CA, Kosten TR, et al. Association between the 5-HTR1B gene polymorphisms and alcohol dependence in a Han Chinese population. Brain Res 2011;1376:1-9. [CrossRef]

33. Cigler T, LaForge KS, McHugh PF, Kapadia SU, Leal SM, Kreek MJ. Novel and previously reported single-nucleotide polymorphisms in the human 5-HT(1B) receptor gene: no association with cocaine or alcohol abuse or dependence. Am J Med Genet 2001;105(6):489-97. [CrossRef]

34. Lee SY, Lin WW, Huang SY, Kuo PH, Wang CL, Wu PL, et al. The relationship between serotonin receptor $1 \mathrm{~B}$ polymorphisms A-161T and alcohol dependence. Alcohol Clin Exp Res 2009;33(9):1589-95. [CrossRef]

35. Chen X, Williamson VS, An SS, Hettema JM, Aggen SH, Neale $\mathrm{MC}$, et al. Cannabinoid receptor 1 gene association with nicotine dependence. Arch Gen Psychiatry 2008;65(7):81624. [CrossRef]

36. Benyamina A, Kebir O, Blecha L, Reynaud M, Krebs MO. CNR1 gene polymorphisms in addictive disorders: a systematic review and a meta-analysis. Addict Biol 2011;16(1):1-6. [CrossRef]

37. Marcos M, Pastor I, de la Calle C, Barrio-Real L, Laso FJ, González-Sarmiento R. Cannabinoid receptor 1 gene is associated with alcohol dependence. Alcohol Clin Exp Res 2012;36(2):267-71. [CrossRef] 